\title{
A Case of 73-Year-Old Male with Chronic Invasive Fungal Sinusitis Mimicking Sino-Nasal Malignancy
}

\author{
Deuktae Cho, Sung-Dong Cho, Hyunkyung Cha, and Hyun Jik Kim (D) \\ Department of Otorhinolaryngology-Head and Neck Surgery, Seoul National University College of Medicine, Seoul, Korea
}

\section{3세 남자 환자에서 발생한 악성 종양으로 오인된 만성 침습성 진균성 부비동염 1예}

조득태 · 조성동 · 차현경 · 김현직

서울대학교 의과대학 이비인후과학교실

\author{
Received May 30, 2020 \\ Revised July 13,2020 \\ Accepted July 15, 2020 \\ Address for correspondence \\ Hyun Jik Kim, MD, PhD \\ Department of Otorhinolaryngology- \\ Head and Neck Surgery, \\ Seoul National University Hospital, \\ Seoul National University \\ College of Medicine, 101 Daehak-ro, \\ Jongno-gu, Seoul 03080, Korea \\ Tel $+82-2-2072-2203$ \\ Fax $+82-2-745-2387$ \\ E-mail hyunjerry@snu.ac.kr
}

Fungal sinusitis is a sinus infection caused by fungal species, most of which are aspergillus species. They can be classified mainly into two groups, invasive fungal sinusitis and non-invasive fungal sinusitis. Invasive fungal sinusitis is characterized by fungi not confined to the paranasal sinuses or the nasal cavity but invading the adjacent tissue and bone. Chronic invasive fungal sinusitis is one type of invasive fungal sinusitis and is a relatively rare disease. It can invade the adjacent sinus bone and tissue for months to years, resulting in bony sclerotic change, formation of mass and bony destruction, which can be mistaken for pseudotumor or malignant tumor. In this report, we report a case of a patient with chronic invasive fungal sinusitis, which was mimicking sino-nasal malignancy.

Korean J Otorhinolaryngol-Head Neck Surg 2021;64(5):354-8

Key Words Cancer of maxillary sinus · Invasive fungal infections · Maxillary sinusitis.

\section{서 론}

진균성 부비동염은 국균, 모균, 캔디다, 히스토플라즈마, 콕 시디오이데스 등의 진균에 의하여 발생하는 감염으로, 대부 분이 국균에 의해 발생한다.1) 진균성 부비동염은 크게 비침 습성과 침습성으로 나눌 수 있다. 침습성 부비동염은 곰팡이 균이 부비동에 국한되어 있지 않고 주변으로 침범되는 것이 특징이며, 침범한 곳에 따라 안면부 통증, 두통, 국소 신경증 상, 안구증상 등이 나타날 수 있다. ${ }^{2.3}$ 침습성 부비동염의 한 분류인 만성 침습성 부비동염은 비교적 드문 질환으로 면역 력이 약화된 환자에게서 발생을 하며 드물게 면역력에 문제 가 없는 사람에게서도 나타난다. 수개월에서 수년에 걸쳐 주 변 조직을 침범하게 되어, 주변 골조직의 경화성 변화 및 골

This is an Open Access article distributed under the terms of the Creative Commons Attribution Non-Commercial License (https://creativecommons.org/licenses/by-nc/4.0) which permits unrestricted non-commercial use, distribution, and reproduction in any medium, provided the original work is properly cited.
손상을 만들고 종괴를 형성하는 경우도 있다. ${ }^{34)}$ 전산화단층 촬영에서는 고음영의 연조직으로 관찰되며, 주변 부비동 벽 을 파괴하는 종괴처럼 관찰되어 악성 종양으로 오인되기도 한다. ${ }^{5}$

저자들은 영상 검사상 악성 종양으로 의심되어 종양 치료 를 목적으로 내원한 환자를 조직 검사를 통해 만성 침습성 진균성 부비동염으로 진단하였고, 이에 대한 치료를 성공적 으로 치험하였기에 문헌 고찰과 함께 보고하고자 한다.

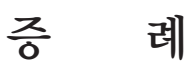

73세 남자 환자가 6개월 전부터 시작된 우측 두통, 코막힘, 간헐적인 코피로 타원 내원하였고, 시행한 전산화단층촬영 (CT)상 부비강암 의심하에 본원 외래를 방문하였다. 과거력 상 진폐증을 가지고 있으나 따로 치료는 받지 않고 있었으며, 당뇨, 고혈압 등 다른 만성 질환은 없었다. 신체 검진상 우측 
상악동 내벽이 살짝 돌출되어 있었으며, 궤양이나 가피는 없 었으나 점막은 창백하였고, 화농성 비루가 관찰되었다. 얼굴, 구강 및 입천장에 특이소견은 없었다. 이전 타원에서 촬영한 $\mathrm{CT}$ 에서 상악동 외측벽과 전벽의 경화성 변화(sclerotic change)와 내벽과 후벽의 골 파괴를 동반한 종괴가 관찰되었 으며, 종괴는 저작근 공간 및 익구개와까지 침범해 있었다. 전 신 양전자단층촬영-자기공명영상(PET-MRI)상 상악동에 비 균질성의 조영 증강된 종괴가 관찰되었으며, CT와 마찬가지 로 주변 조직을 침범하고 있었다. 종괴의 standard uptake value(SUV)는 12.5로 증가되어 있었다(Fig. 1). 외래에서 상 악동 펀치 생검 시행하여 만성 부비동염 진단되었고, 종양이 증거는 관찰되지 않았다. 환자가 고령이며, 골 침범을 동반한 종괴로 부비강암 의심하에 전신 마취하에 내시경하 조직검 사를 시행하였다. 수술장 소견상 상악동 내벽을 파괴하며 중 비도, 하비도로 돌출된 딱딱한 종괴가 관찰되어 깊은 펀치
생검을 시행하였다. 수술 후 얻은 검체에서도 악성 종양의 증 거는 관찰되지 않았으며, 괴사를 동반한 만성 육아종성 염증 소견과 다수의 진균사가 밀집되어 있는 것이 발견되었다. 추 가로 시행한 항산균 염색 및 결핵균 polymerase chain reaction에서는 음성 소견이었고, 진균 확인을 위한 Grocott's methenamine-silver, periodic acid-Schiff 염색에서도 다 수의 진균사가 관찰되었다. 진균은 약 45 도의 균사각을 보이 는 밀집된 균사가 관찰되었으며, 주변 연부조직과 골조직으로 침투된 것이 확인되어, 국균(aspergillosis)에 의한 침습성 진 균성 부비동염으로 진단하였다(Fig. 2). 침습성 진균성 부비 동염에 대한 치료 및 숨어있는 악성 종양에 대한 배제 위하여 내시경하 부비동 수술을 계획하였다. 수술은 구상돌기 절제 술과 전방사골 절제술을 시행한 뒤, 상악동 내벽에서 기인한 딱딱한 종괴가 관찰되어 내벽상악동 절제술(medial maxillectomy)을 시행하였다. 이후 상악동 내 점막에 대하여 광범
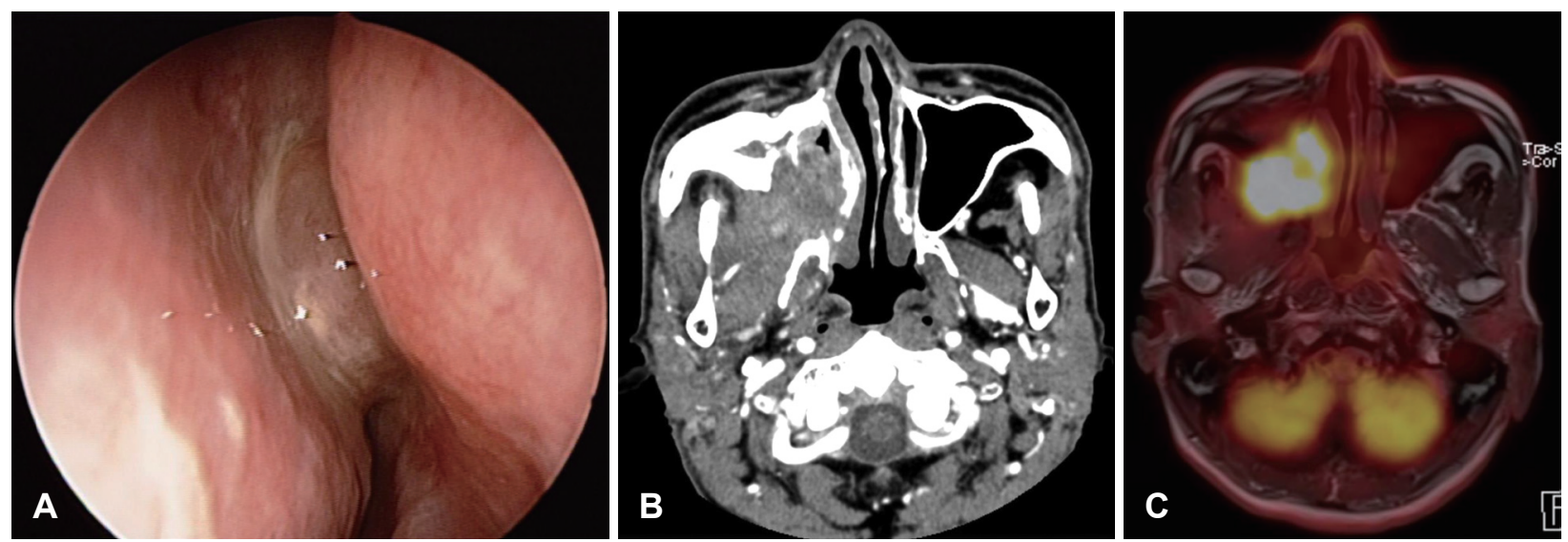

Fig. 1. Endoscopic finding shows that right maxillary sinus medial wall was slightly protruded and purulent discharge was observed (A). In the paranasal sinuses CT, right maxillary sinus anterior and lateral walls were thickened and showed sclerotic change. And mass-like lesion destructed maxillary sinus medial and posterior walls, and also invaded in pterygoid fossa and masticator space (B). In the PETMRI imaging, a large heterogeneous enhancing mass in right maxillary sinus was invaded adjacent tissues, and the standard uptake value of the maxillary sinus mass was increased to 12.5 (C).
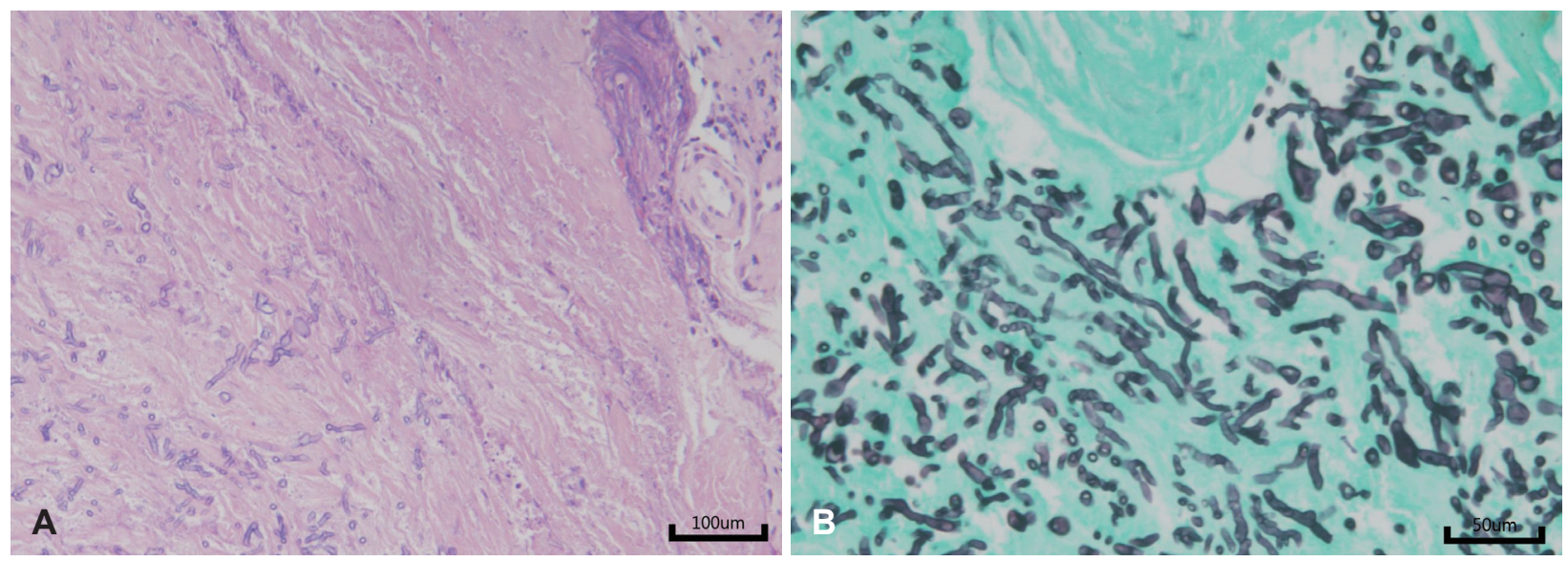

Fig. 2. Histologic findings of chronic invasive fungal sinsutis. There are necrotic debris and dense accumulation of fungus with septal hyphae (hematoxylin and eosin stain, $\times 200)(A)$. GMS staining shows Aspergillus species with septate 45 degree branching hyphae (GMS stain, $\times 400)(B)$. GMS: Grocott's methenamine-silver. 
위한 괴사조직 제거술(debridement)을 시행하였다. 수술 이 후 최종 조직 검사 소견상에서도 국균에 의한 진균 감염이 확진되었으며, 역시 악성 종양의 근거는 관찰되지 않았다. 이 에 우측 익구개와(pterygopalatine fossa) 및 상악동 후방의 진균 감염 치료를 위해 감염내과에 입원하여 voriconazole 경정맥 주사 $(4 \mathrm{mg} / \mathrm{kg})$ 를 시행하였다. 정맥 항진균제 치료 시 작 후 일주일 째 우측 두통 악화 및 우측 안면 감각 저하가 추가로 발생하여 자기공명영상(MRI)을 촬영하였다. MRI 검 사상 이전 $\mathrm{CT}$ 와 비교하여 상악동 내 종괴의 크기는 감소하 였으나, 우측 해면정맥동 및 인접한 경막에 조영 증가된 부분 이 증가하는 소견이 있어(Fig. 3), 염증이 진행된 것으로 판단 하여 즉시 추가로 괴사조직 제거술을 시행하였다. 병변이 일 반적 내시경 접근법으로는 전부 확인이 안될 것으로 판단하 여 변형 얼굴 중간 노출법(modified midfacial degloving approach)을 통하여 상악골 앞벽을 노출 이후 상악동절개하여 상악동으로 접근하였다. 상악동 내 남아있는 종괴들을 제거 하였고, 상악동 후벽, 익구개와 및 상악후부(retromaxillary area)의 괴사된 점막들을 코블레이터로 제거하였다. 수술 이 후 즉시 통증은 완화되었으며, 감각 저하 역시 수술 후 2주 후부터 점차 호전되었다. 총 3주간의 경정맥 voriconazole 사용 이후, 경구 voriconazole(250 mg bid)로 변경하여 퇴원 하였고, 퇴원 이후 추가로 3개월 동안 경구 voriconazole 사 용하였다. 치료 종결 이후 내시경 검진상 수술 부위는 정상 점막으로 뒤덮혀 있어 더 이상의 감염의 증거는 없었으며, 촬 영한 MRI상 우측 해면정맥동 및 인접한 경막의 조영 증강
병변에는 변화는 없었으나, 상악동 종괴의 크기 및 침범 부 위는 크게 감소하였다(Fig. 4). voriconazole 사용 중단 이후 1 년 5개월까지 경과 관찰하였으며, 증상의 재발 및 악화 소 견 없는 상태로(Fig. 5) 외래 경과 관찰 지속 중이다.

\section{고 찰}

진균성 부비동염은 19세기 이전부터 널리 알려진 질환이며, 주변 조직을 침범하는 침습성 부비동염과, 만성 부비동염의 임상양상을 보이는 비침습성 부비동염으로 분류된다. 이후 1997년 deShazo 등은 임상양상, 면역상태, 병리 상태에 따 라서 침습성 부비동염을 급성 전격성, 육아종성 침습성, 만성 침습성 부비동염으로 분류하였다. 급성 전격성 진균성 부비 동염은 심한 면역억제 환자(혈액 암, 장기 이식 수혜자) 등에 서 4주 이내의 단기간에 악화되는 경과를 가지며 생존률도 $50 \%$ 정도로 매우 예후가 불량한 질환이다. ${ }^{6)}$ 조직학적으로는 진균사가 점막, 점막 하, 혈관, 골 등 주변조직을 침윤하며 광 범위한 조직 괴사를 특징으로 한다. 육아종성 침습성 부비동 염의 경우 정상면역인 환자에서 주로 발생하며, 장기간(12주) 에 걸친 편측 안구 돌출증을 주 증상으로 한다. 역시 진균사 의 주변조직 침윤이 관찰되며, 다핵성 거대세포와 비건락성 육아종을 형성, 혈관 주위 섬유화 등의 조직학적 특징을 지 니고 있다. 비교적 예후가 좋아 수술적 치료만으로도 완치될 수 있다. 만성 침습성 부비동염은 주로 당뇨가 있는 환자에서 발생되지만, 정상면역인 환자에서도 발생된다. 12 주 이상에
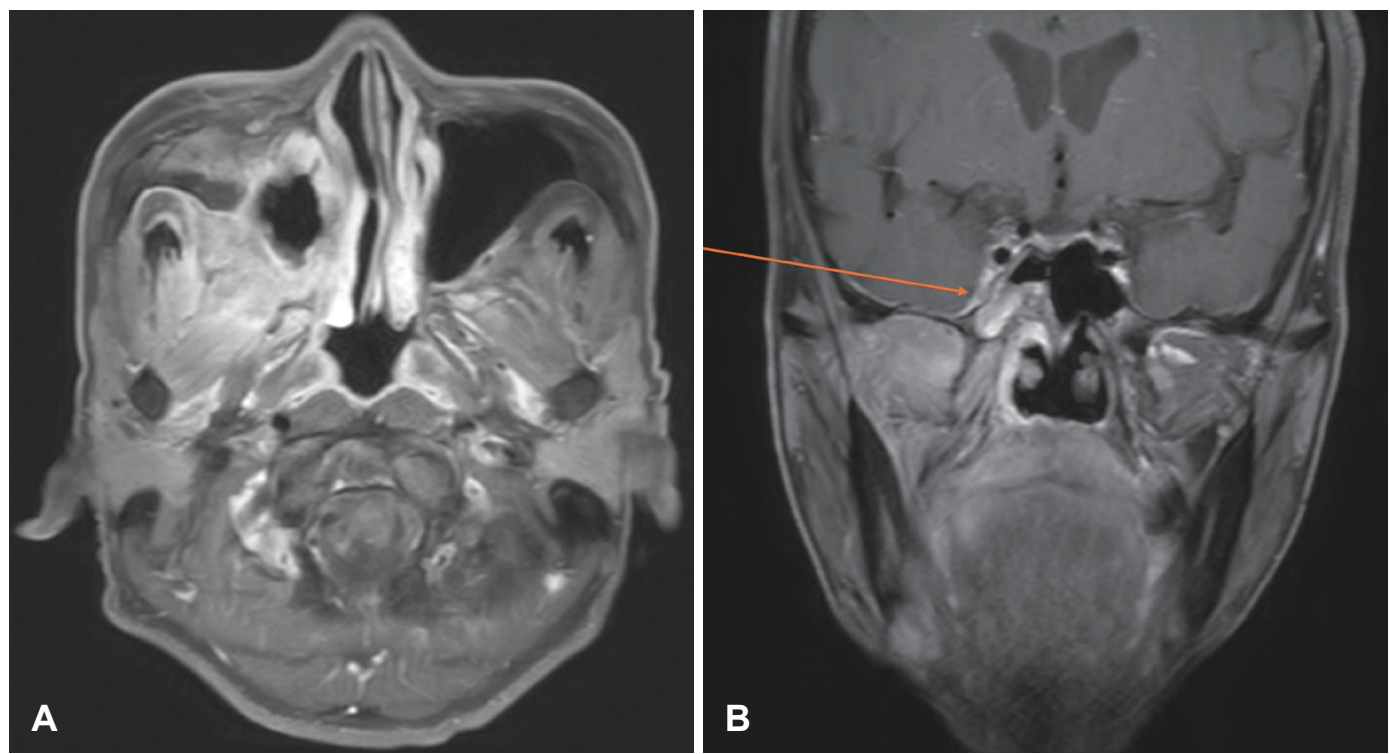

Fig. 3. Paranasal sinuses MR image taken because the patient's symptom was aggravated. MR image show the right maxillary sinus mass size was decreased but masticator space invasion was remained $(A)$. And newly enhancing lesions were detected at right cavernous sinus and adjacent dura (arrow) (B). 

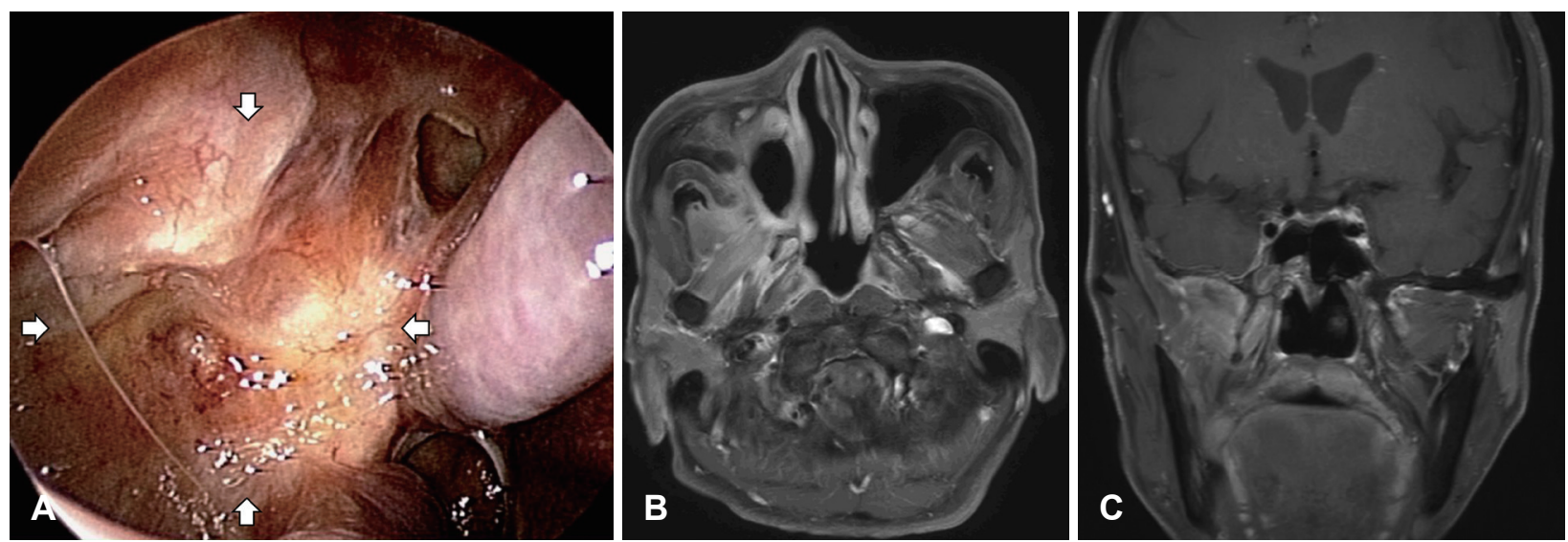

Fig. 4. Endoscopic and paranasal sinuses MR image immediately after end of treatment. Endoscopic finding shows the right maxillary posterior wall (arrows) was covered with normal mucosa (A). In the MRI, the mass and invasion of masticator space were decreased (B). But the enhancing portions of right cavernous sinus and adjacent dura were stationary (C).
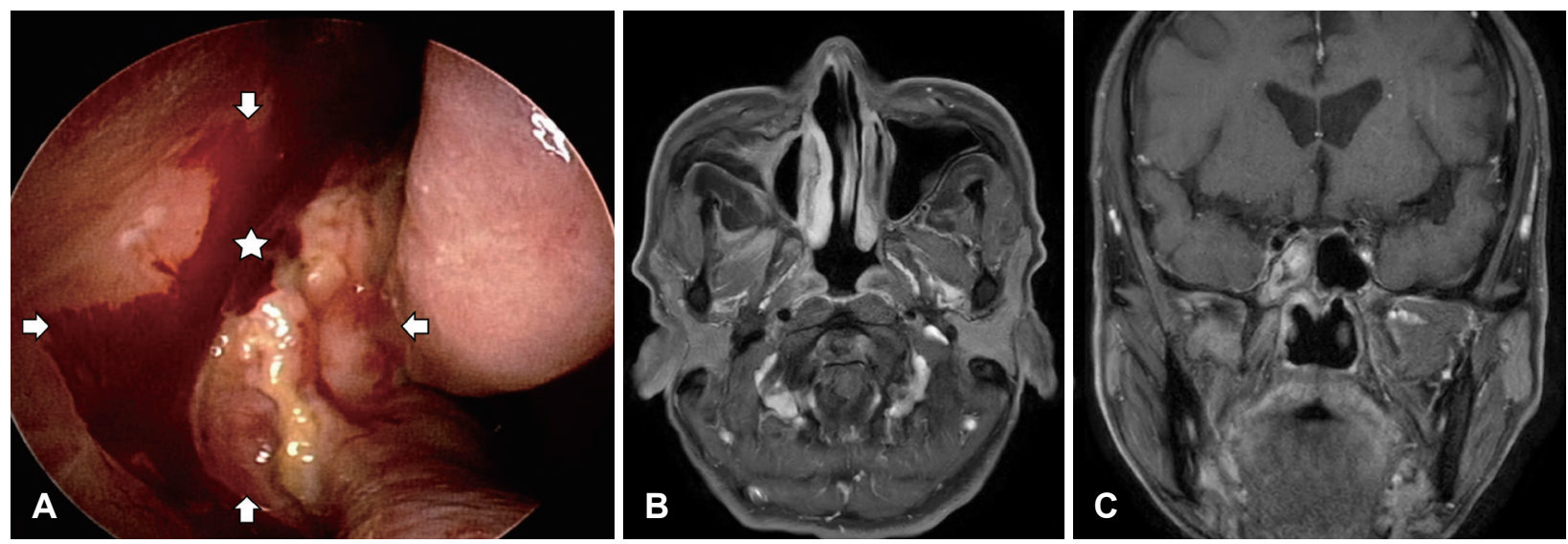

Fig. 5. Endoscopic and paranasal sinuses MR image at 1 year 5 months after last treatment (peroral voriconazole). Endoscopic finding shows healthy mucosa (star) in the right maxillary posterior wall (arrows) (A). On the MRI, the mass and invasion of masticator space were nearly disappeared (B). The enhancing portions of right cavernous sinus and adjacent dura were also decreased (C).

걸친 두통, 비출혈 등 비특이적인 증상이 발생하며, 병변이 진행할 경우 침범 범위에 따라 안구 구획 증후군, 신경학적 증상 등이 증상이 발생할 수도 있다. 조직학적으로는 비교적 저등급의 염증 반응과 동반된 괴사가 특징적이다. 예후는 좋 지 않아 급성 전격성과 같이 적극적인 수술 및 항진균제 치료 가 필요하다. ${ }^{2-47)}$ 본 증례 환자의 경우 6 개월 이상 지속된 안 면통을 호소하였으며, 진균사가 주변조직을 침윤하고, 괴사를 동반하고 있었다. 비록 입원 시 시행한 검사에서 당뇨, 혈액암 등 면역 억제의 소견은 없었으나, 임상 및 병리 양상을 보았을 때, 만성 침습성 진균성 부비동염에 합당한다.

만성 침습성 진균성 부비동염은 비교적 드문 질환으로, 국 내에서도 몇 차례 밖에 문헌 보고되지 않았으며 ${ }^{8,9)}$ 세계적으 로도 소규모의 사례 모음집 밖에 없다. ${ }^{10,11)}$ 치료는 급성 전격 성 진균성 부비동염에 준하여 적극적인 수술적 치료와 항진 균제 사용이 권고되고 있다. 수술적 치료로는 광범위한 괴사 조직 제거술을 시행해야 하는데, 가장자리에서 정상 출혈이
있을 때까지 시행하는 것을 원칙으로 하고 있다. ${ }^{2)}$ 내시경 수 술이 보급된 이후로는, 내시경 수술이 상악동 근치술 못지 않은 치료 성적을 내고 있으며, 수술 후 합병증을 최소화하고 있어 선호되고 있으나, 내시경 수술만으로 병변의 완전한 제 거가 불가능하다면 추가적인 상악동 근치술 등이 필요하다. 하지만 광범위 상악동 절제술, 두개 안면 절제술, 안구적출술 같은 근치적 수술은 생존률 향상에 도움을 주지 못한다고 알려져 있어 환자의 상태에 따른 적절한 수술적 치료 방침 결정이 중요하다. ${ }^{12)}$ 병의 초기에 치료를 시작하는 것과 병의 유발인자를 조절하는 것이 생존률 향상에 도움이 된다고 알 려져 있다. 침습성 부비동염의 의심될 경우 빠른 조직검사를 통한 진단을 하고, 조기에 항진균제를 사용하며, 동반된 유발 인자에 대한 엄격한 조절하는 것이 중요하다. ${ }^{13)}$ 수술 이후에 는 amphotericin $\mathrm{B}(0.23 \sim 1.0 \mathrm{mg} / \mathrm{kg} / \mathrm{day})$ 를 병의 경중에 따 라서 6 8주간 사용해야 한다. ${ }^{2}$ 본 증례처럼 국균에 의한 침 습성 부비동염의 경우에는 voriconazole을 사용하는 것이 
amphotericin B보다 효과가 좋은 것으로 알려져 있다. voriconazole을 하루 동안 $6 \mathrm{mg} / \mathrm{kg}$ 씩 두 번 경정맥 주사로 부하 용량으로 사용한 이후에, 최소 1 주일간 $4 \mathrm{mg} / \mathrm{kg}$ 씩 두 번 경정 맥 주사로 사용해야 하며, 경구약으로 전환한 경우 $200 \mathrm{mg}$ 로 두 번씩 복용하여 총 12 주간의 항진균제 사용이 필요하다. ${ }^{14}$

DelGaudio 등 ${ }^{15)}$ 에 의해 시행된 연구에 따르면, 침습성 진 균성 부비동염이 있는 환자군의 전산화단층촬영 검사에서 비강 내 점막이 편측성으로 심하게 두꺼워있는 것을 확인할 수 있었으나, 이것은 만성 부비동염에서도 관찰될 수 있는 비 특이적인 소견이었으며, 침습성 부비동염의 초기에는 CT에 서 골미란이나 부비강 외 침범이 관찰되지 않기 때문에, $\mathrm{CT}$ 에만 의존하여 진단하는 것은 피하고, 빠른 내시경적 검사와 필요 시 조직검사를 시행하는 것을 권유하였다. 또한, Ariban$\mathrm{di}$ 등ㅎํ에 의해 시행된 연구에 따르면 만성 침습성 부비동염 의 경우 CT에서 부비동 내 고음영 부분이 나타나고 부비동 골벽의 파괴 및 경화성 변화를 보이기 때문에 악성 종양으로 오인될 수 있다고 하였고, 영상의학적 검사만으로는 만성 진 균성 부비동염과 악성 종양의 감별은 불가능하다고 하였다.

본 증례의 경우, 특별한 면역 억제 질환을 가지고 있지 않은 고령의 환자에서 영상의학적 검사상 광범위한 골 파괴 및 주 변 조직을 침범하는 소견과 PET 검사상 높은 SUV 값을 보 여주고 있었다. 이에 저자들은 악성 종양을 강력하게 의심하 였고, 외래에서 첫 시행한 조직검사가 만성 염증성 소견이 나 왔을 때, 추가적인 진균 염색 등을 거치지 않았다. 이후 전신 마취 하에 추가 조직검사를 진행한 후에야 최종적으로 침습 성 진균성 부비동염으로 진단되어 수술적 및 항진균제 치료 시작 시점이 지체되었던 어려움이 있었다. 항진균제 치료 중 증상의 악화가 있어 병의 진행됨을 확인한 이후에는 즉각적 인 괴사제거수술을 시행함으로써 좋은 치료 결과를 가져올 수 있었다.

본 증례에서처럼 부비동에 광범위한 골 파괴를 동반하는 종괴가 있는 환자에서 악성 종양을 의심하여야 하겠지만, 조 직 검사상 암세포가 관찰되지 않을 경우에는 항상 만성 침습 성 진균성 부비동염을 염두에 두어 적극적인 조직검사와 진 균염색 등을 통하여 빠른 진단과 치료가 필요할 것으로 생각 된다.

\section{Acknowledgments}

None.

\section{Author Contribution}

Conceptualization: Hyun Jik Kim. Data curation: Hyunkyung
Cha. Formal analysis: Sung-Dong Cho. Methodology: Sung-Dong Cho. Project administration: Hyun Jik Kim. Visualization: Hyunkyung Cha. Writing — original draft: Deuktae Cho. Writingreview \& editing: Hyun Jik Kim.

\section{ORCID}

Hyun Jik Kim ～https://orcid.org/0000-0001-8631-928X

\section{REFERENCES}

1) Romett JL, Newman RK. Aspergillosis of the nose and paranasal sinuses. Laryngoscope 1982;92(7 Pt 1):764-6.

2) Shin SH, Clinical characteristics and treatment of fungal rhinosinusitis. Korean J Otorhinolaryngol-Head Neck Surg 2011;54(7):454-61

3) deShazo RD, Chapin K, Swain RE. Fungal sinusitis. N Engl J Med 1997;337(4):254-9.

4) Chakrabarti A, Denning DW, Ferguson BJ, Ponikau J, Buzina W, Kita H, et al. Fungal rhinosinusitis: A categorization and definitional schema addressing current controversies. Laryngoscope 2009; 119(9):1809-18.

5) Aribandi M, McCoy VA, Bazan C 3rd. Imaging features of invasive and noninvasive fungal sinusitis: A review. Radiographics 2007;27(5):1283-96.

6) Payne SJ, Mitzner R, Kunchala S, Roland L, McGinn JD. Acute invasive fungal rhinosinusitis: A 15-year experience with 41 patients. Otolaryngol Head Neck Surg 2016;154(4):759-64.

7) deShazo RD, O’Brien M, Chapin K, Soto-Aguilar M, Gardner L, Swain R. A new classification and diagnostic criteria for invasive fungal sinusitis. Arch Otolaryngol Head Neck Surg 1997;123(11): 1181-8.

8) Lee IW, Yoon BW, Hong SL, Cho KS. A case of chronic invasive fungal sinusitis after endoscopic sinus surgery for chronic rhinosinusitis. Korean J Otorhinolaryngol-Head Neck Surg 2014;57(7):477-80.

9) Kim DK, Nam SK, Lee KA, Cho JH. A case of chronic invasive fungal sinusitis invading pterygopalatine fossa. Korean J Otorhinolaryngol-Head Neck Surg 2010;53(5):316-9.

10) D’Anza B, Stokken J, Greene JS, Kennedy T, Woodard TD, Sindwani R. Chronic invasive fungal sinusitis: Characterization and shift in management of a rare disease. Int Forum Allergy Rhinol 2016;6(12):1294-300.

11) Webb BJ, Vikram HR. Chronic invasive sinus aspergillosis in immunocompetent hosts: A geographic comparison. Mycopathologia 2010;170(6):403-10.

12) Lee BJ, Kim H, Kim JH, Kim YJ, Fungal sinusitis: Clinical features and treatment outcomes with emphasis on endoscopic sinus surgery. Korean J Otolaryngol 1998;41(3):318-22.

13) Lee MC, Song JJ, Jung HS, Lee SS, Rhee CS, Lee CH, et al. Prognostic factors of invasive fungal sinusitis. Korean J Otolaryngol 2003;46(10):841-5.

14) Herbrecht R, Denning DW, Patterson TF, Bennett JE, Greene RE, Oestmann JW, et al. Voriconazole versus amphotericin B for primary therapy of invasive aspergillosis. N Engl J Med 2002;347(6):408-15.

15) DelGaudio JM, Swain RE Jr, Kingdom TT, Muller S, Hudgins PA. Computed tomographic findings in patients with invasive fungal sinusitis. Arch Otolaryngol Head Neck Surg 2003;129(2):236-40. 